Arq. Bras. Med. Vet. Zootec., v.67, n.1, p.125-130, 2015

\title{
Blood parameters and measurements of weight in the rehabilitation of Magellanic penguins (Spheniscus magellanicus, Foster 1781)
}

[Parâmetros sanguíneos e medidas de peso na reabilitação de pinguins-de-Magalhães (Spheniscus magellanicus, Foster 1781)

\author{
A.M. Martins ${ }^{1,2}$, R.P. Silva Filho ${ }^{2}$, M.O. Xavier $^{2}$, M.C.A. Meireles ${ }^{1}$, R.B. Robaldo ${ }^{1}$ \\ ${ }^{1}$ Universidade Federal de Pelotas - UFPel - Pelotas, RS \\ ${ }^{2}$ Universidade Federal do Rio Grande - FURG - Rio Grande, RS
}

\begin{abstract}
During the austral winter the appearance of the Magellanic penguin (Spheniscus magellanicus) is common on the southern coast of Brazil. The oil pollution constitutes a major cause of death of these birds. The monitoring of the weight and blood variables is important to make decisions during the rehabilitation and release of these animals. Thus, the aim of this study was to evaluate the relationship between the penguins' survival during rehabilitation and the values of hematocrit (Hct), total plasma protein (TPP) and body weight (BW) of the birds received at Centro de Recuperação de Animais Marinhos (Recovery Centre for Sea Animals) between 2006 and 2009. The analysis took place weekly, and penguins were classified according to the outcome of the rehabilitation process, when 101 specimens were rehabilitated and released, and 67 died. Released animals showed a decrease in the Hct in the second and third weeks ( $41 \pm 6 \%$ and $40 \pm 5 \%$ respectively) followed by recovery of the values in the fourth and fifth week $(41 \pm 4 \%$ and $43 \pm 4 \%$ respectively). TPP levels increased steadily over the collections, stabilizing at $7.3 \pm 0.8 \mathrm{~g} / \mathrm{dL}$ in the fourth week. On the other hand, animals that died, although following the same response for TPP, showed no significant difference in Hct between collections, and showed a tendency for loss of BW in the last weeks of rehabilitation. The curves of BW and Hct during rehabilitation were considered a potential prognostic indicator of penguins in rehabilitation. Animals that arrived at the recovery centre with BW, Hct and TPP above $2.700 \mathrm{~g}, 45 \%$ and $5.6 \mathrm{~g} / \mathrm{dL}$, respectively, have a greater chance of recovery, making these parameters crucial points in decision making regarding the treatment to be conducted during rehabilitation.
\end{abstract}

Keywords: Sphenisciformes, oiled, hematocrit, total plasma protein, weight

\section{RESUMO}

Durante o inverno austral, é comum o aparecimento do pinguim-de-Magalhães (Spheniscus magellanicus) no litoral sul do Brasil. A poluição por petróleo constitui a maior causa de morte dessas aves. $O$ acompanhamento do peso e de variáveis sanguíneas é importante para a tomada de decisões durante a reabilitação e liberação desses animais. $O$ objetivo deste estudo foi avaliar a relação entre a sobrevivência dos pinguins durante a reabilitação e os valores de hematócrito (Ht), proteínas plasmáticas totais (PPT) e peso corpóreo (PC) das aves recebidas no Centro de Recuperação de Animais Marinhos entre 2006 e 2009. As análises ocorreram semanalmente, e os pinguins foram classificados em função do desfecho do processo de reabilitação, quando 101 espécimes foram reabilitados e liberados e 67 foram a óbito. Animais liberados

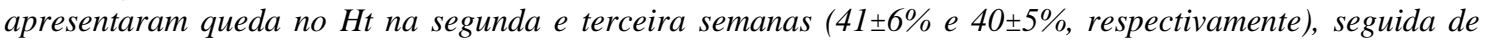
recuperação dos valores na quarta e quinta semanas $(41 \pm 4 \%$ e $43 \pm 4 \%$, respectivamente). Os níveis de PPT aumentaram progressivamente ao longo das coletas, estabilizando na quarta semana em 7,3 $\pm 0,8 \mathrm{~g} / \mathrm{dL}$. Em contrapartida, animais que foram a óbito, apesar de seguirem a mesma resposta para as PPT, não apresentaram diferença significativa do Ht, entre as coletas, e demonstraram tendência à perda de PC nas últimas semanas de reabilitação. As curvas de PC e Ht foram consideradas indicadoras potenciais de prognóstico durante a reabilitação dos pinguins. Animais que chegaram ao centro de recuperação com $\mathrm{PC}, \mathrm{Ht}$ e PPT acima de $2.700 \mathrm{~g}, 45 \%$ e 5,6g/dL, respectivamente, apresentaram maior chance de recuperação, fazendo

Recebido em 28 de julho de 2013

Aceito em 7 de agosto de 2014

E-mail: arysemartins@gmail.com 
desses parâmetros pontos críticos na tomada de decisão quanto ao tratamento a ser conduzido durante a reabilitação.

Palavras-chave: Sphenisciformes, despetrolização, hematócrito, proteínas plasmáticas totais, peso

\section{INTRODUCTION}

The Magellanic penguins (Spheniscus magellanicus Foster, 1781) are distributed in colonies located on the Pacific and Atlantic coasts of South America, ranging from $42^{\circ} \mathrm{S}$, following to Tierra del Fuego on the Atlantic side, until $29^{\circ} \mathrm{S}$ on the Pacific side. Moreover, there are colonies in the Falkland Islands $\left(54^{\circ} \mathrm{S}\right)$ (Williams, 1995). They are pelagic in autumn and austral winter and come back to their colonies in spring, staying there until the end of summer, in April (Boersma et al., 1990). Every winter, initially directed by the cold ocean current from the Falkland Islands, following the anchovy clusters (Engraulis anchoita), these penguins arrive on the Brazilian coast, up to Rio de Janeiro, although some individuals have already been seen up to the coast of Fortaleza (Silva-Filho andRuoppolo, 2006).

Although major accidents involving oil and oil product spills may have serious consequences, the chronic pollution of the ocean is the leading cause of death of seabirds (Gandini et al., 1994; Ruoppolo e Silva-Filho, 2004). It is estimated that every year 3.2 million tonnes of hydrocarbon are poured into the sea, being 0.47 million tonnes from vessels or handling oil during its extraction (Heredia et al., 2008). On the coast of Rio Grande do Sul, the pollution by oil in the seas is also a major problem, causing mortality of several species, such as albatrosses, petrels and shearwaters. However, the penguins are the most affected birds (Petry et al., 2002).

On the coast of the South Atlantic Ocean there are 25 rehabilitation groups of seabirds, from Santo Antônio do Oeste, in Argentina, to Salvador, in Brazil. Most of these rehabilitation centres are near seaports, terminals and oil platforms (García-Borboroglu et al., 2006).

During the rehabilitation process, haematological analyses have proved to be effective to monitor the health status of the animals (Newman et al., 1997). The monitoring of blood variables has proved to be very effective throughout the experiments in emergencies (Russel et al., 2003).

The hematocrit (Hct) represents the portion of red blood cells in relation to the total blood volume (Lorenzi et al., 1999). This test is commonly used for diagnosis of anaemia and dehydration and for monitoring the health status of animals in rehabilitation (Campbell, 1994). High values may indicate dehydration while low values may indicate anaemia (Russell et al., 2003).

The total plasma protein (TPP) is also important for monitoring the health status of penguins in rehabilitation. Over 100 different proteins form an important part of the plasma, especially the albumin and globulin. The albumin influences the osmotic pressure of the plasma and it is essential to the transport of some substances, such as hormones and lipids, in the body circulation. At the same time, the globulin act in the infectious and inflammatory processes (Lorenzi et al., 1999).

Thus, monitoring the Hct, the TPP and the body weight (BW) are important tools for the rehabilitation process of penguins, informing the health status of the animal, featuring the possibility of release or the need for measures to stabilize these values.

This study aimed to evaluate the parameters of health status during the process of rehabilitation of captive Magellanic penguins, relating the Hct, TPP and BW throughout the rehabilitation process.

\section{MATERIALS AND METHODS}

The study was conducted at Centro de Recuperação de Animais Marinhos (CRAMFURG), next to the Oceanographic Museum "Prof. Eliézer de Carvalho Rios" (32 1' 3374"S; $\left.52^{\circ} 06^{\prime} 21.01^{\prime \prime} \mathrm{O}\right)$ belonging to the Federal University of Rio Grande (FURG), located in the city of Rio Grande, Rio Grande do Sul, Brazil. 
All specimens of Magellanic penguins found on the beaches of the southern coast of Rio Grande do Sul and submitted to CRAM-FURG between 2006 and 2009 were included in the study.

The collections were made for five consecutive weeks, once a week, starting on the day the animal was received at the centre up to the moment before release, for survey and data analyses of hematocrit, total plasma protein and body weight.

The weighing was performed on an electronic scale with accuracy of $5 \mathrm{~g}$. The blood was collected from the medial metatarsal vein, using $21 \mathrm{G}$ hypodermic needles, and arranged in heparinised micro capillary tubes, which were centrifuged for five minutes at $12,000 \mathrm{rpm}$. The hematocrit (Hct) resding was held on ruler "Critocaps $®$ Micro-Hematocrit Capillary Tube Reader". The levels of total plasma protein (TPP) were measured on a clinical refractometer with a resolution of $0.2 \% \mathrm{sg}$ (specific gravity) and protein measuring range of $0-12 \mathrm{~g} / \mathrm{dL}$. The data were sequentially recorded for each specimen, observing the rehabilitation outcome (release or death).

The weekly averages of Hct, TPP and BW were compared by ANOVA followed by the Tukey test. The comparison of the initial averages of these variables in relation to death or release was done with the Student's t-test. All analyses considered a significance level of $5 \%$. The STATISTICA 7.0 software (StatSoft, 2004) was used for statistical processing.

\section{RESULTS AND DISCUSSION}

A total of 168 Magellanic penguins were received at CRAM-FURG between 2006 and 2009 . Of these, 101 were released $(60 \%)$ and 67 (40\%) died during rehabilitation.

By comparing the initial Hct in animals that have reached release $(46 \pm 6 \%)$ or death $(37 \pm 12 \%)$ during five weeks of rehabilitation, it was observed that the released animals showed a higher value of Hct than those which came to death. This demonstrates that the animals' anemic framework when they arrived at the centre is responsible for a lower chance of survival during their rehabilitation (Tseng, 1993; Newman, 1997).
In released animals the values of Hct tend to decrease in the second and third weeks, increasing again in the fourth and fifth collection, showing an average Hct of $43 \pm 4 \%$, which is considered to be homeostatic for this species (Fig. 1). According to Silva-Filho and Ruoppolo (2006), this is an issue for the possible release of the animal. This response pattern can be explained by the animals' dehydration when they arrived at CRAM-FURG, which is quelled in the process of stabilization by fluid therapy (Robinson, 2000). After fluid therapy and feeding the penguins, the body fluid compartments and the red blood series are resettled, so that the hematocrit is adjusted to values considered to be normal for the species (Hawkey et al., 1989; Ruoppolo et al., 2004). The values of Hct found in the released animals in the end of rehabilitation were similar to those described by Hawkey et al. (1989) for free Magellanic penguins $(42 \pm 4 \%)$.

Russel et al. (2003) observed that prior to the routine of using the values of Hct as criteria for conducting the washing and/or releasing of the birds, a high rate of mortality post-release was accounted. From the moment the determination of Hct became a tool, combined with normal weight, waterproofing of feathers and typical behaviour of the species for decision of release, a decrease in mortality was observed. With the results found in this study, we can consider the Hct not only as an important tool for the decision of release, but also as an important tool for conducting the treatment during the period of rehabilitation of Magellanic penguins.

Considering the values of TPP regarding the penguins' outcome, it was observed that released animals showed levels of initial TPP of $5.8 \pm 1.1 \mathrm{~g} / \mathrm{dL}$, higher than in the animals that died $(4.5 \pm 1.5 \mathrm{~g} / \mathrm{dL})$. This suggests that these animals could have been on a dietary deficiency for longer, which reduced their plasma proteins (Ghebremeskel et al., 1989). Tseng (1993) suggests that birds that show a concentration of TPP below $2.0 \mathrm{~g} / \mathrm{dL}$ should have a different diet with protein supplementation. From the data obtained in this study, for Magellanic penguins it is suggested that such supplementation should be given to the animals that show TPP below $4.5 \mathrm{~g} / \mathrm{dL}$. 


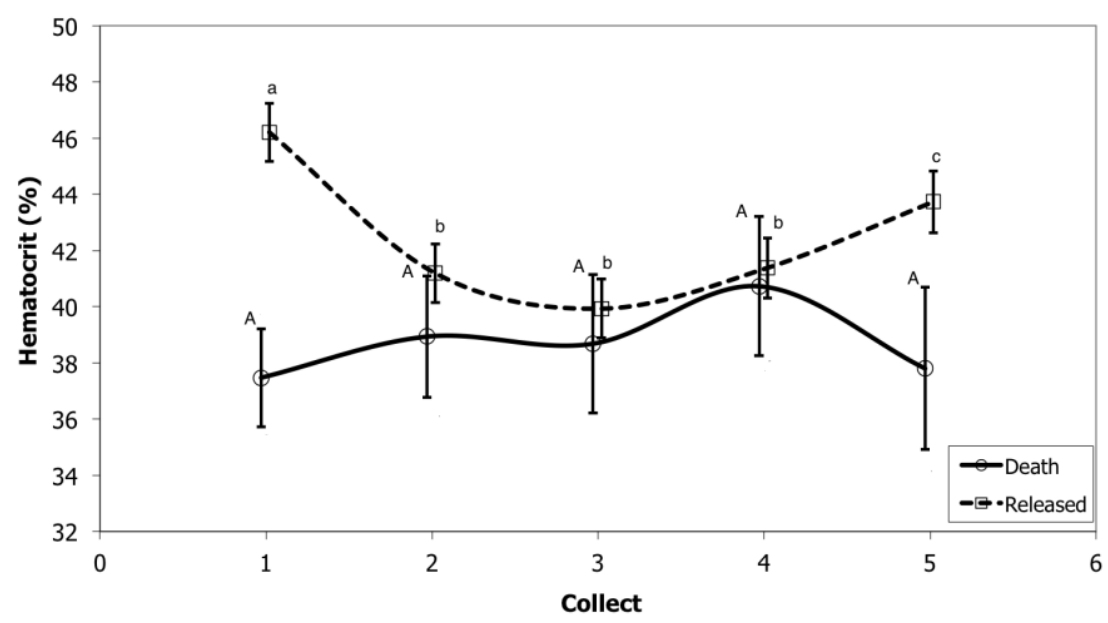

Figure 1. Variation of hematocrit over five weekly collections in Magellanic penguins Spheniscus magellanicus. Different lowercase letters represent significant difference between the averages of released animals, and different capital letters represent a significant difference between the averages of animals that died (ANOVA; Tukey; $\mathrm{P}<0,05$ ).

In the animals that died there was a tendency to increase the concentration of TPP according to the increase of time in rehabilitation. The same happened to the released animals (Figure 2). However, it should be taken into account that the average initial concentration of TPP in the released birds was significantly higher than in the birds that died. Villouta et al. (1997) observed a decrease in the Humboldt penguins' average concentration of TPP in the second collection (three weeks after the first) and an increase in the third and fourth collection (seven and fifteen weeks after the first, respectively). The increase of proteins in the penguins of this study as well as in the Humboldt penguins may be related to a controlled diet with protein supply received in captivity.

Regarding the penguins' weight, it was observed that, in the first collection, rehabilitated animals showed a significantly higher average $(2,742 \pm 508 \mathrm{~g})$ than the animals that died $(2,383 \pm 495 \mathrm{~g})$. Travis et al. (2006) observed that male Galapagos penguins are significantly heavier than females. However, gender was not taken into account in this study, considering that these animals have no sexual dimorphism and the determination of certainty is held by autopsy, which is only possible in animals that died or by DNA test, which is still not applied in the routine of a rehabilitation centre due to its high cost.
Vanstreels et al., (2011) suggests a new method for sexing Magellanic penguins through morphometric measurements, which have accuracy between $80 \%$ and $90 \%$. However, it was not possible to use this methodology in this study for lack of data. The body condition would be a more appropriate method to infer about the animal's nutritional status, but there is still no formula that calculates the body mass index of penguins.

The rehabilitated penguins showed a significant difference in weight between the collections, tending to increase weight according to the increase of time in rehabilitation (Figure 3), The increase in weight may be the result of the appropriate treatment given to the animals, with a balanced diet, vitamin replacement and thermal comfort supply, resulting in improvement of their body conditions (Robinson, 2000).

Penguins that died remained without significant change in weight between the second and fifth collection. This absence of significant gain in weight during rehabilitation, when the animals receive any nutritional intake necessary for their recovery, may be related to the manifestation of symptoms of a disease, such as aspergillosis, for example, which may have resulted in the death of these animals (Xavier et al., 2007). 


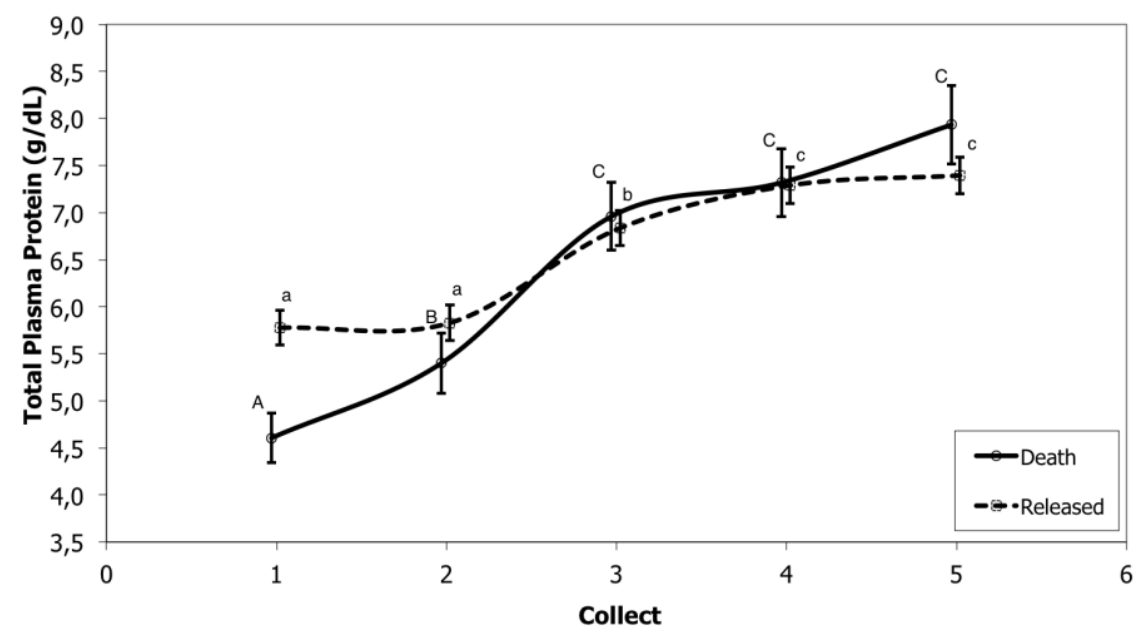

Figure 2. Variation of Total Plasma Protein over five weekly collections in Magellanic penguins Spheniscus magellanicus. Different lowercase letters represent a significant difference between the averages of released animals, different capital letters represent significant difference between the averages of animals that died (ANOVA; Tukey; $\mathrm{P}<0.05$ ).

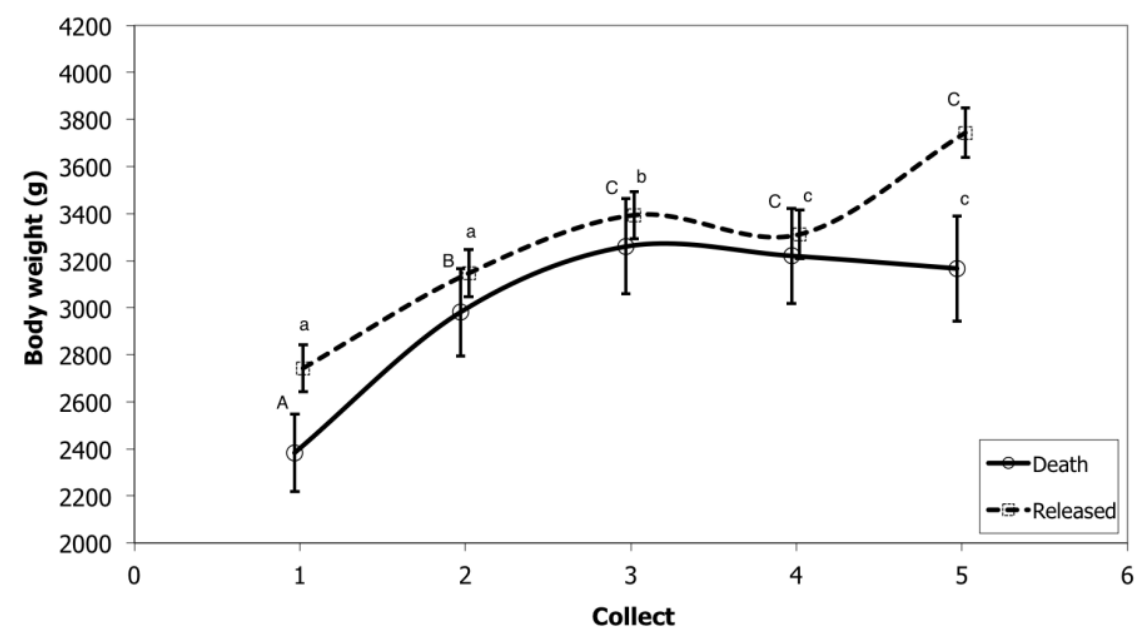

Figure 3. Variation of body weight over five weekly collections in Magellanic penguins Spheniscus magellanicus. Different lowercase letters represent a significant difference between the averages in released animals, and different capital letters represent a significant difference between the averages in animals that died (ANOVA; Tukey; $\mathrm{P}<0.05$ ).

\section{CONCLUSION}

Specimens of Magellanic penguins that arrive at the rehabilitation centre weighing more than $2,700 \mathrm{~g}$, with hematocrit above $45 \%$ and levels of total plasma protein higher than $5.6 \mathrm{~g} / \mathrm{dL}$ have a greater chance of recovery. These values, therefore, must represent a crucial point in the decision making regarding the treatment to be conducted during rehabilitation. At the same time, the results show that it is necessary to deepen the study of the causes that lead to a health condition below the critical point indicated, so that it is possible to determine alternative procedures for the rehabilitation protocol that has been applied to these animals and, therefore, optimize the rehabilitation process. 


\section{REFERENCES}

BOERSMA, P.D.; STOKES, D.L.; YORIO, P.M. Reproductive variability and historical change of Magellanic penguins (Spheniscus magellanicus) at Punta Tombo, Argentina. In: DAVIS, L.S; DARBY, J.T. (Ed). Penguim Biology. San Diego: ACADEMIC PRESS, 1990. p.15-43.

CAMPBELL, T.W. Hematology. In: RITCHIE, B.W.; HARRISON, L.R. (Ed). Avian Medicine: Principles e Application. Florida: WINGERS PUBLISHING, 1994. p.176-198.

GANDINI, P.; BOERSMA, P.D.; FRERE, E. et al. Magellanic penguins (Spheniscus magellanicus) affected by chronic petroleum pollution along coast of Chubut, Argentina. The Auk, v.111, p.20-27, 1994.

GARCÍA-BORBOROGLU, P.; BOERSMA, P.D.; RUOPPOLO, V. et al. Chronic oil pollution harms Magellanic penguins in the Southwest Atlantic. Marine Poll. Bull., v.52, p.193-198, 2006.

GHEBREMESKEL， K.; WILLIAMS， G.; KEYMER, I.F. et al. Plasma chemistry of Rockhopper (Eudyptes crestatus), Magellanic (Spheniscus magellanicus), and Gentoo (Pygoscelis papua) wild penguins in relation to molt. Comp. Biochem. Physiol., v.92A, p.43-47, 1989.

HAWKEY, C.M.; HORSLEY, D.T.; KEYMER, I.F. Haematology of wild penguins (spenisciformes) in the falkland islands. Avian Pathol., v.18, p.495-502, 1989.

HEREDIA, S.A.R.; ALVAREZ, C.K.; LOUREIRO, J.D. (Ed). Aves Marinas Empetroladas: guia para su manejo y atención. San Clemente: FUND. MUNDO MARINO, 2008. 139p.

LORENZI, T.F. Introdução à fisiologia hematológica. In: AIRES, M.M. (Ed). Fisiologia. Rio de Janeiro: GUANABARA KOOGAN, 1999. p.101-124.

NEWMAN, S.H.; PIATT, J.F.; WHITE, J. Hematological and plasma biochemical reference ranges of Alaskan seabirds: their ecological significance and clinical importance. Colon. Waterbird., v.20, p.492-504, 1997.
PETRY, M.V.; FONSECA, V.S.S. Effects of human activities in the marine environment on seabirds along the coast of Rio Grande do Sul, Brazil. Ornitol. Neotrop., v.13, p.137-142, 2002.

ROBINSON, I. Seabirds. In: TULLY Jr., T.N.; DORRESTEIN, G.M.; JONES, A.K. (Ed). Handbook of Avian Medicine. Woburn: SAUNDERS, 2000. p.339-363.

RUOPPOLO, V.; SILVA-FILHO, R.P. A Reabilitação de fauna em derramamentos de petróleo. Clin. Vet., v.50, p.78-80, 2004.

RUSSEL, M.; HOLCOMB, J.; BERKNER, A. 30-Years of Oiled Wildlife Response Statistics. In: PROCEEDINGS OF THE $7^{\mathrm{TH}}$ INTERNATIONAL EFFECTS OF OIL AND WILDLIFE CONFERENCE, 2003, Hamburg, Germany. 2003. p.1-18.

SILVA-FILHO, R.P.; RUOPPOLO, V. Sphenisciformes (Pinguim). In: CUBAS, Z.S.; SILVA, J.C.R.; CATÃO-DIAS, J.L.(Ed) Tratado de Animais Selvagens-Medicina Veterinária. São Paulo: ROCA, 2006. p.309-323.

TRAVIS, E.K.; VARGAS, F.H.; MERKEL, J. et al. Hematology, serum chemistry, and serology of Galápagos penguins (Spheniscus mendiculus) in the Galápagos islands, Ecuador. J. Wildl. Dis., v.42, p.625-632, 2006.

TSENG, F. Care of oiled seabird: a veterinary perspective. In: OIL SPILL CONFERENCE, 1993, Washington. 1993. p.421-424.

VANSTREELS, R.E.T.; ADORNES, A.C.; RUOPPOLO, V. Gender determination from morphometrics in migrating Magellanic Penguins Spheniscus magellanicus. Marine Ornithol. v.39, p.215-220, 2011.

VILLOUTA, G.; HARGREAVES, R.; RTVEROS, V. Haematological and clinical biochemistry findings in captive Humboldt penguins (Spheniscus humboldti). Avian Pathol., v.26, p.851-858, 1997.

XAVIER, M.O; SOARES, M. P.; MEINERZ, A. R. et al. Aspergillosis: a limiting factor during recovery of captive magellanic penguins. Braz. J. Microbiol., v.38, p.480-484, 2007.

WILLIAMS, T.D. (Ed). Bird families of the world - The Penguins. New York: OXFORD UNIVERSITY PRESS, 1995. 352p. 